IIIIIIIIIIIIIIIIIIIIIIIIIIIIIIII

読み物シリーズ

IIIIIIIIIIIIIIIIIIIIIIIIIIIIIIII

農薬に係る法律・入門編

\title{
特定化学物質の環境への排出量の把握等及び管理の 改善の促進に関する法律（化管法：PRTR制度）
}

\author{
高 橋 知 史* \\ 三浦工業株式会社・環境事業本部
}

（2015年11月 20 日受理）

\section{Act on Confirmation, etc. of Release Amounts of Specific Chemical Substances in the Environment and Promotion of Improvements to the Management Thereof (PRTR Law)}

\author{
Tomofumi TAKAHASHI
}

\begin{abstract}
MIURA CO., LTD., Environmental Business Headquarters, 864-1 Hojo Tsuji, Matsuyama, Ehime 799-2430, Japan
\end{abstract}
Keywords: PRTR, SDS, chemical substances, release amounts.

は じめに

「特定化学物質の環境への排出量の把握等及び管理の改善 の促進に関する法律」(以下「法, 法律」という) が, 平成 11年7月に公布された. 本法律の略称には, 化学物質排出把 握管理促進法, または単に化管法がある. 本法律は, PRTR 制度とSDS制度を柱として, 事業者による化学物質の自主 的な管理の改善を促進し，環境の保全上の支障を未然に防 止することを目的とした法律である ${ }^{1)}$.ここで，PRTRとは Pollutant Release and Transfer Registerの略であり, 日本語 訳ではPRTR制度のことを污染物質排出移動登録制度とい う. SDSとはSafety Data Sheetの略であり, 日本語訳では SDS制度のことを安全データシート制度という. SDS制度に ついて先に述べると，化学物質を適正に管理するには，事業 者は取り扱う化学物質やそれを含有する製品について，その 成分や取り扱い方法を知っておく必要がある。そのため本法

\footnotetext{
*\%799-2430 愛媛県松山市北条辻 864-1

E-mail: takahashi_tomofumi@miuraz.co.jp

(c) 日本農薬学会
}

律では, 指定した化学物質等について, 事業者が他の事業者 に対し変渡し，または提供するときは，その相手方に対し， SDSを提供することが義務化されている。これがSDS制度 である。なお，本稿ではSDS制度の詳細については割愛す る.

PRTR制度とは，人の健康や生態系に有害なおそれのある 化学物質が, 事業所から環境 (大気, 水, 土㙥) 一排出され る量及び廃棄物に含まれて事業所外へ移動する量を, 事業者 自ら把握し国に届け出て, 国は届出データや推計に基づき, 排出量・移動量（以下，「排出量等」という）を集計して公 表する制度である ${ }^{2)}$. 平成 13 年 4 月から実施されている制度 であるが, 実際に届出するとなると, 本法律の理解だけでは 困難な部分もあるため, 実務者としてはPRTR排出量等算出 マニュアル ${ }^{3)}$ を参照しながら, ある程度の知識と経験を備 えた者が，煩雑な作業に当たる必要がある，そこで本稿では 実務者・研究者向けに, 本法律の概要を解説するとともに, 届出の対象範囲を判定する手順及び排出量等の算出手順につ いても解説する. 


\section{1. 法律の目的と狙い}

本法律の目的は，法第一条において次のようにまとめられ ている.「この法律は，環境の保全に係る化学物質の管理に 関する国際的協調の動向に配慮しつつ，化学物質に関する科 学的知見及び化学物質の製造, 使用その他の取扱いに関する 状況を踏まえ，事業者及び国民の理解の下に，特定の化学物 質の環境への排出量等の把握に関する措置並びに事業者によ る特定の化学物質の性状及び取扱いに関する情報の提供に関 する措置等を講ずることにより，事業者による化学物質の自 主的な管理の改善を促進し，環境の保全上の支障を未然に防 止することを目的とする.」

これにより，特定の化学物質を扱う事業者は，事業活動に 伴って発生する化学物質について環境（大気, 水, 土壌）へ の排出量, 及び廃棄物への移動量を把握して, 毎年都道府県 に届け出なければならない. 国はこれらのデータを集計後, 各事業所からの排出量及び移動量を事業所名とともに国民に 公開する。 そのため, 事業者は取り扱う化学物質について, 自主的に管理を改善したり，積極的に排出量削減活動に取り 組むことが期待されている。また，国や自治体には，集計 データを用いて環境対策を講じることが期待されている。そ の結果として，化学物質による環境の保全上の支障を未然に 防止することが本法律の目的と狙いである ${ }^{4)}$.

\section{2. 制定の背景}

制定の背景については，経済産業省の平成 25 年度 PRTR データの概要 ${ }^{4)}$ から抜粋させて頂く.

現在の我々の生活は多数の化学物質を使用し, 利用するこ とによって成り立っているが，これらの化学物質の中には， 人の健康や動植物の生息・生育に悪影響を及ぼすおそれがあ る性状を有しているものも少なくないため，それらの物質に よる環境の污染に関する国民の不安が増大している.

しかし，さまざまな化学物質による複合的な影響を含め て, 現に存在する数多くの化学物質による人の健康や生態系 への影響に関して十分な科学的知見を整備するためには極め て長い時間と膨大な費用を要することから，そのような科学 的知見の充実を背景とした厳格な法規制を中心とする従来の 対策手法には限界があることが指摘されている.

このような状況を踏まえ，国際的には，平成 4 年，国連環 境開発会議（地球サミット）で採択された「アジェンダ $21 」$ の第19章において化学物質の管理の問題が取り上げられた のを受け，平成 8 年 2 月には, OECD (経済協力開発機構) により PRTR制度の導入勧告が行われた.

また，産業界においても，化学工業界における自主的な PRTR事業の実施，事業者間における化学物質の安全性に関 する情報提供を目的としたSDSの普及，レスポンシブル。 ケア活動（企業が自主的に化学物質に関して環境・安全・健
康面の対策を行うこと）が進められている.

このような国際的取組及び産業界における自主的な取組の 状況，さらには国民・産業界・行政の連携等をも視野に入れ つつ，より効果的な環境りスク対策の手法が求められている ことを背景として, 平成11年7月13日に本法律が公布され, 我が国においても，同法に基づくPRTR制度が導入されるこ ととなった.

また，この法律の施行 7 年後の見直しとして，平成 19 年 2 月から, 中央環境審議会及び産業構造審議会の合同会合にお いて, PRTR制度, SDS制度, 事業者による化学物質の自主 的な管理の改善等の要素ごとに, 施行状況の評価, 課題の整 理，措置の検討が行われ，平成 19 年 8 月に中間とりまとめ として公表された，本中間とりまとめでは，対象物質・対象 事業者・届出事項の見直しや, 届出・推計データの多面的利 用の促進等, 制度の見直しと運用の改善等を検討し, 必要な 措置を講じることとされている.

これを受けて, 薬事・食品衛生審議会, 化学物質審議会, 中央環境審議会の合同会合において対象物質の見直しに係る 検討を行い，平成 20 年6月に報告がとりまとめられ，その 結果を受けて, 平成 20 年 11 月に, 対象物質の見直し（従来 の第一種指定化学物質 354 物質に代えて, 新たに 462 物質を 指定）及び第一種指定化学物質等取扱事業者になり得る業種 への医療業の追加を内容とする, 化学物質排出把握管理促進 法施行令（以下「令, 施行令」という）の改正を行った。こ れらの新たな対象物質及び対象業種については, 平成 22 年 度から事業者による排出量等の把握が開始され, 平成 23 年 度から事業者による届出及び国による届出外排出量（事業者 により届出される以外の排出量）の推計等が開始された。

また，平成 22 年 4 月には，事業者がPRTR制度に基づき届 出を行う際に用いる様式への廃棄物の処理方法等の届出事項 の追加及び届出事項の集計を効率的に行うための二次元コー ドの採用等を内容とする, 化学物質排出把握管理促進法施行 規則（以下「施行規則」という）の改正を行った。平成 23 年度から，新たな様式による届出が開始された。

\section{3. 主な内容と解説}

本法律の構成は,

第一章 総則（第一条～第四条）

第二章 第一種指定化学物質の排出量等の把握等（第五条 ～第十三条）

第三章 指定化学物質等取扱事業者による情報の提供等 （第十四条～第十六条）

第四章 雑則（第十七条～第二十三条）

第五章 罰則（第二十四条）

となっている.

PRTR制度に関する法律，施行令，施行規則の対照を表 1 に示す。これより，実務者・研究者が届け出るにあたって特 
表 1. PRTR制度に関する法律, 施行令, 施行規則の対照

\begin{tabular}{|c|c|c|c|c|c|c|}
\hline & \multicolumn{2}{|r|}{ 法律 } & \multicolumn{2}{|r|}{ 施行令 } & \multicolumn{2}{|r|}{ 施行規則 } \\
\hline 章 & 条 & 表題（・要旨） & 条 & 表題 & 条 & 表題 \\
\hline \multirow[t]{4}{*}{ 一 } & 第一条 & 目的 & & & & \\
\hline & 第二条 & $\begin{array}{l}\text { 定義等 } \\
\text { ・化学物質とは } \\
\text { • 第一種指定化学物質とは } \\
\text { • 第二種指定化学物質とは } \\
\text { • 化学物質の悪影響を配慮 } \\
\text { ·第一種指定化学物質等取扱事 } \\
\text { 業者とは } \\
\text { • 指定化学物質等取扱事業者と } \\
\text { は }\end{array}$ & $\begin{array}{l}\text { 第一条 } \\
\text { 第二条 } \\
\text { 第三条 } \\
\text { 第四条 } \\
\text { 第五条 } \\
\text { 第六条 }\end{array}$ & $\begin{array}{l}\text { 第一種指定化学物質（別表第一） } \\
\text { 第二種指定化学物質（別表第二） } \\
\text { 業種 } \\
\text { 第一種指定化学物質等取扱事業者の } \\
\text { 要件 } \\
\text { 法第二条第五項第一号の政令で定め } \\
\text { る要件 } \\
\text { 法第二条第六項の政令で定める要件 }\end{array}$ & & \\
\hline & 第三条 & 化学物質管理指針 & & & & \\
\hline & 第四条 & 事業者の責務 & & & & \\
\hline \multirow[t]{9}{*}{ 二 } & 第五条 & $\begin{array}{l}\text { 排出量等の把握及び届出 } \\
\text { ・事業者による第一種指定化学 } \\
\text { 物質の排出量, 移動量の把握 } \\
\text { ・事業者による毎年度の届出 } \\
\text { •届出は都道府県知事を経由す } \\
\text { る }\end{array}$ & 第九条 & $\begin{array}{l}\text { 磁気ディスクによる届出又は請求の } \\
\text { 方法 }\end{array}$ & $\begin{array}{l}\text { 第一条 } \\
\text { 第二条 } \\
\text { 第三条 } \\
\text { 第四条 } \\
\text { 第五条 } \\
\text { 第六条 } \\
\text { 第十一条 } \\
\text { 第十二条 } \\
\text { 第十三条 } \\
\text { 第十四条 }\end{array}$ & $\begin{array}{l}\text { 用語 } \\
\text { 第一種指定化学物質の排出量の算 } \\
\text { 出の方法 } \\
\text { 第一種指定化学物質の移動量の算 } \\
\text { 出の方法 } \\
\text { 排出量及び移動量の把握 } \\
\text { 届出の方法等 } \\
\text { 届出事項 } \\
\text { 電子情報処理組織を使用した届出 } \\
\text { の方法 } \\
\text { 事前の届出等 } \\
\text { 磁気ディスクによる届出等の方法 } \\
\text { 磁気ディスクにはり付ける書面 }\end{array}$ \\
\hline & 第六条 & 対応化学物質分類名への変更 & & & $\begin{array}{l}\text { 第七条 } \\
\text { 第八条 }\end{array}$ & $\begin{array}{l}\text { 対応化学物質分類名 } \\
\text { 対応化学物質分類名への変更等の } \\
\text { 請求の方法 }\end{array}$ \\
\hline & 第七条 & 届出事項の通知等 & & & 第九条 & 都道府県知事が説明を求める方法 \\
\hline & 第八条 & 届出事項の集計等 & & & & \\
\hline & 第九条 & $\begin{array}{l}\text { 届け出られた排出量以外の排出 } \\
\text { 量の算出等 }\end{array}$ & & & & \\
\hline & 第十条 & 開示請求権 & & & & \\
\hline & 第十一条 & 排出量等の開示義務 & 第十条 & 磁気ディスクによる開示の方法 & & \\
\hline & 第十二条 & 調査の実施等 & & & & \\
\hline & 第十三条 & 資料の提供の要求等 & & & & \\
\hline \multirow[t]{3}{*}{ 三 } & 第十四条 & $\begin{array}{l}\text { 指定化学物質等の性状及び取扱 } \\
\text { いに関する情報の提供 }\end{array}$ & & & & \\
\hline & 第十五条 & 勧告及び公表 & & & & \\
\hline & 第十六条 & 報告の徵収 & & & & \\
\hline \multirow[t]{7}{*}{ 四 } & 第十七条 & 国及び地方公共団体の措置 & & & & \\
\hline & 第十八条 & 審議会等の意見の聴取 & 第七条 & 審議会等で政令で定めるもの & & \\
\hline & 第十九条 & 手数料 & 第八条 & 手数料の額等 & 第十条 & 手数料を現金により納付できる場合 \\
\hline & 第二十条 & 磁気ディスクによる届出等 & & & & \\
\hline & 第二十一条 & 経過措置 & & & & \\
\hline & 第二十二条 & 主務大臣等 & & & & \\
\hline & 第二十三条 & 事務の区分 & & & & \\
\hline 五 & 第二十四条 & 罰則 ～～～～ & & & & \\
\hline
\end{tabular}


に重要となるのは，法第二条と法第五条関連になる。ただ し, 本稿では条文の解説は割愛し, 実務における届出対象事 業者と届出対象物質の判定手順と, 排出量等の基本的な算出 手順の二つについて解説したいと思う ${ }^{3,5}$.

\section{1. 届出対象事業者と届出対象物質の判定手順}

PRTR届出の対象となる事業者は, 以下の三つの要件をす べて満たす事業者であり, 要件を一つでも満たさない事業者 は届出は不要である.

(1) 対象業種を営んでいる事業者

(2) 常時使用する従業員の数が 21 人以上の事業者

(3) 取报量等の要件として次のどちらかに該当する事業者

a）年間取扱量が指定量以上である対象物質を取り扱う事 業所を有する事業者

b）特別要件施設を有する事業者

上記の要件を判定するには, 本法律や用語を理解し, それ ぞれの項目について調査を行い，手順を追って判定すると いった煩雑な作業が必要になるため, 届出対象事業者の判定 方法について，以下に具体的に解説する ${ }^{3)}$.

な扔，対象事業者から届出された排出量以外の届出外排出 量は, 国が推計することとなっているが, 具体的には, 上記 要件を満たさない事業者からの排出量や, 家庭からの排出 量, 移動体 (自動車, 船舶, 鉄道車両, 航空機等) からの排 出量が該当する. 平成 25 年度の公表データによると, 総排 出量に占める届出排出量の割合は $40 \%$, 届出外排出量の割 合は $60 \%$ となっている.

\subsection{1. 業種の判定}

事業者が，令第三条に記載された 24 の対象業種を営んで いるかを確認する．24の対象業種を表2に示す。この業種分 類は日本標準産業分類（平成 5 年改定）に準拠している。な お，兼業している業種が一つでも該当すれば，対象業種を営 んでいることになる。本稿の読者は, 製造業, 商品検査業, 計量証明業 (一般計量証明業を除く), 高等教育機関, 自然 科学研究所等に該当される方が多いのではないだろうか.

\subsection{2. 常時使用する従業員の数の判定}

本社及び全国の支社・出張所等を含めた，すべての事業所 の従業員の数を合算して 21 人以上かどうかを確認する. 21 人以上であれば対象である。ここで，常時使用する従業員と は, 当該年度の 4 月 1 日の時点で期間を定めずに使用されて いる人もしくは1 ケ月を超える期間を定めて使用されている 人や，前年度の 2 月及び 3 月中にそれぞれ 18 日以上使用され ている人，上記に該当する嘱託・パート・アルバイトと呼ば れる人が該当する.

3.1.3. 対象物質の年間取扱量の判定を行う事業所の調査 年間取报量等の判定を行う, 対象業種に属する事業が行わ れている事業所を調查する。例えば, ある会社において, 契 約や人的管理のみを行う「本社事務所」と, 金属パネルの塗
表2. 対象業種一覧

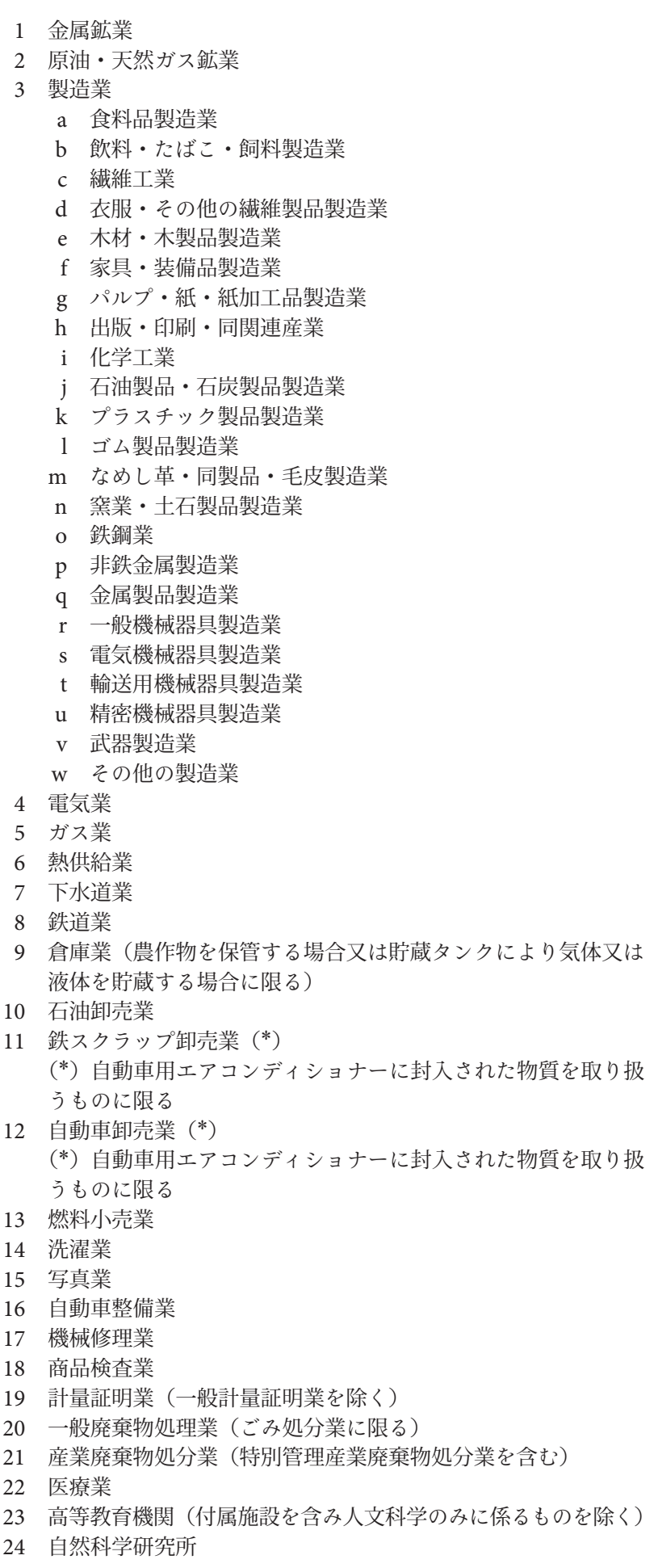

注：公務はその行う業務によりそれぞれの業種に分類して扱い，分 類された業種が上記の対象業種であれば同様に届出対象.

装を行う「塗装工場」がある場合, 対象業種に属する事業が 行われている事業所は「塗装工場」であって,「本社事務所」 は該当しない。したがって, 対象物質の年間取扱量等の判定 
を行う事業所は「塗装工場」のみとなる.

3.1.4. 対象物質の年間取扱量の判定

事業所ごとに，対象物質の年間取扱量を以下の手順(1) (6) で算出し，その結果が次の指定量以上となる対象物質が一つ 以上ある場合は，届出対象事業者となる．ここで，単位中の $\mathrm{t}$ はton（トン）を示す.

- 対象物質（第一種指定化学物質） $1 \mathrm{t} /$ 年

- 対象物質のうち, 特定第一種指定化学物質 $0.5 \mathrm{t} /$ 年

な打, 製造量・使用量等の変動や事業内容の変更, 排出削 減対策の実施などにより, 届出対象となる事業所や物質が変 わる可能性があるため, 年間取扱量の判定は毎年行う. 以下 に手順(1)〜6)を示す.

(1) 対象物質の年間製造量の確認

対象物質を製造しているかどうかを確認し，その年間製造 量を確認する。いずれの対象物質も製造していない事業所は $0 \mathrm{t} /$ 年となる.

(2) 使用する原材料, 資材等の形状の確認

事業活動として，次に示す形状の原材料，資材等の使用の 有無を確認する。そして，以下に示すものは使用量を把握す る必要がある。

・気体または液体のもの

・固体のもので固有の形状を有しないもの（粉末状のものなど）

・固体のうち固有の形状を有するもので取扱いの過程で溶 融，蒸発または溶解するもの

・精製や切断等の加工に伴い環境中に排出されるもの ただし, 以下に示すものは使用量を把握する必要はない。

- 対象物質の含有量が $1 \%$ （特定第一種指定化学物質の場合 は $0.1 \% ）$ 未満の製品

・固形物（粉状や粒状のものを除く）

・密封された状態で使用される製品（例：乾電池など）

・一般消費者用の製品（例：家庭用洗剂，殺虫剂など）

・再生資源（例：空き缶など）

(3) 原材料, 資材等に含まれる対象物質の調查

SDS等から次の值以上の含有率の対象物質があるかどうか を確認する.

- 対象物質（第一種指定化学物質） 1 重量\%

- 対象物質のうち, 特定第一種指定化学物質 0.1 重量\%

(4) 原材料, 資材等の年間使用量の算出

原材料, 資材等の年間使用量を以下の算出式で算出する.

$$
\mathrm{A}=\mathrm{B}-\mathrm{C}+\mathrm{D}
$$

$\mathrm{A}$ ：原材料，資材等の年間使用量 $(\mathrm{t} /$ 年 $)$

$\mathrm{B}$ ：原材料，資材等の年間購入量 $(\mathrm{t} /$ 年 $)$

$\mathrm{C}:$ 原材料, 資材等の年度末在庫量 $(\mathrm{t})$

$\mathrm{D}$ ：原材料, 資材等の年度初めの在庫量 $(\mathrm{t})$

(5) 対象物質の年間使用量の算出

対象物質の年間使用量を以下の算出式で算出する。なお，
複数の原材料，資材等に同じ対象物質が含まれる場合は，同 じ対象物質を含む原材料，資材等の分をすべて合計する.

$$
\mathrm{E}=\mathrm{A} \times \mathrm{F} \div 100
$$

$\mathrm{E}:$ 対象物質の年間使用量（ $\mathrm{t} /$ 年 $)$

$\mathrm{A}$ ：原材料，資材等の年間使用量（ $\mathrm{t} /$ 年）（手順(4)の算 出結果)

F：原材料，資材等に含まれる対象物質の含有量（\%)

(6) 対象物質の年間取报量の算出 対象物質の年間取扱量を以下の算出式で算出する.

$$
G=H+E
$$

$\mathrm{G}$ : 対象物質の年間取扱量（ $\mathrm{t} /$ 年）

$\mathrm{H}$ : 対象物質の年間製造量（ $\mathrm{t} /$ 年) (手順1 1 の調査結果)

$\mathrm{E}:$ 対象物質の年間使用量 ( $\mathrm{t} /$ 年) (手順(5)の算出結果) 算出した年間取扱量と次の指定量を比較して, 届出対象事 業者となるか，及び届出の対象となる物質を判別する.

- 対象物質（第一種指定化学物質） $1 \mathrm{t} /$ 年

- 対象物質のうち, 特定第一種指定化学物質 $0.5 \mathrm{t} /$ 年 3.1.5. 特別要件施設の判定

前述した対象物質の年間取扱量の判定結果にかかわらず, 以下に示す特別要件施設を設置している事業者は, 届出対象 事業者となる。なお, 届出対象物質は, 特別要件施設から排 出される排ガス・排水等において，それぞれの法律で定めら れた測定対象物質（例えばダイオキシン類等）である.

・金属鉱業又は原油及び天然ガス鉱業を営む事業者におけ る, 鉱山保安法に規定する建設物, 工作物その他の施設

・下水道業を営む事業者における，下水道終末処理施設

・ごみ処分業又は産業廃棄物処分業を営む事業者における, 一般廃棄物処理施設又は産業廃棄物処理施設

・いずれかの対象業種を営む事業者における, ダイオキシン 類対策特別措置法に規定する特定施設

以上のすべての要件を満たす場合に, 届出対象事業者と判 定される。

\section{2. 排出量等の基本的な算出手順}

上述の手順により届出対象事業者と判定されれば，届出対 象物質の排出量等を算出する必要がある。排出量等を把握す るまでのポイントは以下の三つである.

(1) 化学物質がどこから排出されているか. 排出のされ方に どのような特徴があるかを把握する。

(2) 算出の際に，どのような情報が必要で，それが入手でき るかを把握し，適切な算出方法を用いる。

(3) 算出結果にどの程度の不確かさがあるかを把握する. ここでは, 排出量等の把握の精度を上げることが重要にな る. 特に, 事業内容の変更や排出削減対策が実施された場合 は, 算出に当たって考慮されている工程・排出ポイント, 対 
象物質の範囲が, 現状と合わなくなることがある。また, 法 施行以降に新しい実測の方法等, 技術的な情報が整備されて きたことから，より精度の高い算出方法が使用できるように なった場合もある.このような場合には算出方法を見直し， 精度の高いものにしていくことが重要である. 以下に算出手 順を解説する。

3.2.1. PRTRで届け出るデータの種類

届出の対象物質ごとに, 排出量（四つ）, 移動量（二つ） の届出の分類に区分して届け出る.

(1) 排出量

-大気への排出量

大気への排出量は，排気口や煙突等からの排出だけでな く，パイプの継ぎ目からの漏洩や，開放場所での塗装による 溶剂成分の揮発等も対象となる。

・公共用水域への排出量

工程排水, 排水処理施設からの排出, 反応容器などの洗浄 水等を, 河川, 湖沼, 海等へ放流している場合が対象となる.

・当該事業所における土壌への排出量

タンク，パイプ等からの漏洩や，工程排水や洗浄排水等の 地中への意図的な地下浸透等が対象となる。

- 当該事業所における埋立処分量

各工程から発生する廃棄物や，容器やタンクの残留物等 を，事業者が同一の事業所内の埋立地へ埋め立てている場合 が対象となる。

(2) 移動量

-下水道への移動量

工程排水，排水処理施設からの排出，反応容器などの洗浄 水等を, 下水道へ放流している場合が対象となる.

・当該事業所の外への移動量

各工程から発生する廃棄物や, 容器やタンクの残留物等を, 産業廃棄物処理業者に処分を委託する場合が対象となる。

3.2.2. 化学物質の排出ポイント, 排出の特徵を把握する 際の考え方

排出量等の算出結果を確からしいものとするためには, 化 学物質の排出ポイントや排出の特徽を正確に把握し, 重要な 排出ポイントや排出量が大きい季節・時間等について, 算出 の対象範囲から漏れ・抜けがないようにすることが重量であ る.なお，上記を把握の際は，業界団体で作成されている業 種別マニュアル等も参考になる.

また，一般的な排出ポイントの他に，当該事業所に特有の 排出ポイントがないかを検討，考慮すれば，算出結果はより 確かなものになる。

3.2.3. 排出量等の基本的な算出方法の考え方

排出量等の算出方法には以下の四つの基本的な方法があるが, より精度よく算出できると思われる経験值等を用いてもよい，

(1) 物質収支による方法

対象物質の年間取扱量から製品としての搬出量及び実測や
排出係数などから算出した他の排出量と移動量を差し引いて 算出する方法である.

この方法は, 施設や工程全体の対象物質の流れの把握に有 効であり，計算で算出するので低コストであるといった利点 がある．ただし，年間取扱量や搬出量等の精度に依存するの

で，それらの誤差をできる限り小さくする必要がある.

(2) 実測による方法

事業所の主要な排出口における排ガス，排水または廃棄物 中の対象物質濃度を実測して，それぞれの量とかけ合わせて 算出する方法である.

この方法は，他の法令にもとづき，対象物質の濃度を測定 している場合，その值を利用できる。また，排ガスや排水処 理装置を設置している場合, 回収や除去能力を同時に確認で きるといった利点がある. 但し, 測定值の変動や精度に気を つける必要がある。

(3) 排出係数による方法

対象物質の年間取扱量に，モデル実験等で別途算定した取 扱量と排出量の比（排出係数）をかけ合わせて算出する方法 である。

この方法は, 取扱量の調査だけで容易に排出量が算出でき るので，排出係数がある場合は低コストであるといった利点 がある，但し，マニュアル等に記載された排出係数は，必ず しも実態を反映していないので, 自社の経験等をもとにした 排出係数がある場合はそれを使用する.

(4) 物性值を用いた計算による方法

飽和蒸気圧や水への溶解度等により対象物質の排ガス又は 排水中の濃度を推測して，それぞれの量とかけ合わせて算出 する方法である。

この方法は，算出に用いるデータは各種便覧等から入手で きるため，実測等と比較して低コストであるといった利点が ある。但し，実態にあう条件を設定するには，化学工学的知 識が必要である。また, 対象物質が単成分であればデータを 利用できるが，他の物質が混合した多成分であれば，データ をそのまま使用できないことがある。

3.2.4. 排出量等の基本的な算出の手順

排出量等の算出手順は, 「特別要件施設以外からの算出手 順」と,「特別要件施設からの算出手順」の二つに分けられ るが，本稿では前者について，以下の手順(1)〜6)を簡単に解 説する.

(1) 製造品としての搬出量等の算出

製造品の製造量等に，対象物質の含有率等を乗じて算出する。

(2) 廃棄物に含まれる量の算出

廃棄物の発生量に, 対象物質の含有率等を乗じた值である.

(3) 環境への最大潜在排出量の算出

対象物質の年間取扱量から，製造品としての搬出量と廃棄 物に含まれる量を差し引いた值である。ここで, 環境への最 大潜在排出量とは, 環境へ排出される可能性のある最大の量 
のことである.

(4) 土㙴への排出量の算出

土袞へ漏出した原材料や資材等の量に, 対象物質の含有率 を乗じた值である。

(5) 大気，水域の排出量の多い方と少ない方の判定

大気と水域への排出量のどちらが多くなりそうで，どちら が少なくなりそうであるかを，対象物質の性状や取り扱い方 法，ヘンリ一定数等を考慮して判定する。なお，ヘンリ一定 数の大きい物質が大気へ排出されやすい，そして，排出量の 少ない方への排出量は，実測や排出係数，物性值を用いた計 算による方法で算出する。一方，排出量の多い方への排出量 は，環境への最大潜在排出量から，土㙵啡出量及び排出 量の少ない方への排出量を差し引いた量になる.

(6) 排出量等の集計

算出した排出量と移動量を届出の分類に区分して集計する. 3.2.5. 算出結果の確からしさを把握する際の考え方

上述の算出結果がどの程度確からしいかを把握し，使用し ている算出方法のどこに，どの程度の改善の余地があるのか を知っておくことは有用である。

算出結果の確からしさを把握することは，ある程度技術的 な知識と経験を必要とするが, 事業者の実状にあわせて可能 な範囲で対応することが望ましい，その場合は，使用した算 出方法が有する誤差の洗い出しや, 誤差のオーダーの把握と いった定性的な把握，あるいは，専門家による見積やシミュ レーションといった定量的な把握の実施を検討する.

\section{PRTR データの取り扱い上の注意点}

PRTRデータを取り扱う上での注意点は以下のとおりである.

(1) 届出排出量と届出移動量の限界

届出は, 要件を満たした事業者のみが行うため, 届出され た排出量等がすべての事業者からの排出量等を示しているの ではない，また，排出量等は，実測值に基づき算出する方法 以外に，物質収支や排出係数を用いて算出する方法など，事 業者が適当と判断した方法で把握されている。 よって, 必ず しもすべてが実測值に基づくものではなく，その精度には一 定の限界がある. なお, 届出值の有効数字は 2 析である.

(2) 届出外排出量の限界

届出外排出量は, 想定される主要な排出源を対象に国が 推計を行っているが，すべての排出源を網羅したものではな い. また，その精度には一定の限界がある。ささらに，届出外 排出量については, 毎年, 推計手法の改善が進められてお り, 推計手法の変更が終了するまでは, 年度ごとの推計值を 単純に比較できない点も注意が必要である。

(3) 公表データによるリスク評価の限界

公表データは制度に基づく排出量等の集計值であり, 環境 中で人や動植物が実際にさらされる化学物質の量 (暴露量) ではないし，リスクの大小を直接表すものでもない.

\section{PRTR公表データの例}

最後に, PRTR公表データから二つの例を示したいと思 う。上述した注意点に留意して参照して頂きたい。

(1) 届出排出量等の合計量の上位物質の推移

国の集計結果から，国内の届出排出量等の合計における 上位3物質（トルエン，キシレン，エチルベンゼン）につい て, 推移を図 1 に示す。

ここで, トルエンとキシレンは, 主に溶剤・合成原料, 自 動車等の排出ガス, 接着剤・塗料として使用されており, エ チルベンゼンは, 主に溶剤として使用されている化学物質で ある. 特にトルエンとキシレンについては, 年々, 届出排出 量等が減少していることがわかる，もちろん経済状況の変化 といった要因もあるかもしれないが，PRTR制度の目的であ る「事業者は取り扱う化学物質について, 自主的に管理を改 善したり, 積極的に排出量削減活動に取り組む」ことを目標 に掲げて, 多くの事業者が取り組んでいる成果ではないだろ うか.

(2) 当社公表データの例

著者が所属する三浦工業株式会社（北条工場）における， トルエンとキシレンについて, 届出排出量等の推移を図 2 に 示す.

当社の事業内容は, 小型貫流ボイラに代表される各種ボイ ラの製造や水処理機器等の製造を主体としており，業種は一 般機械器具製造業に該当する. トルエンやキシレンの排出量 が多いのは, 機械製品の塗装用途があることと, 著者が所属

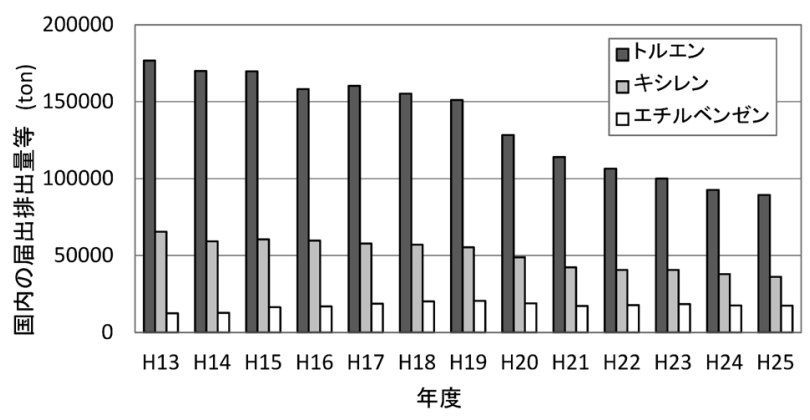

図1. 国内の届出排出量等の合計に打け上位3物質の推移.

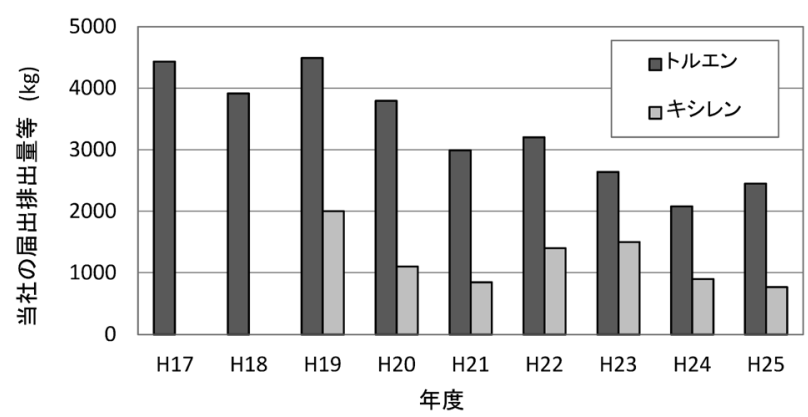

図2. 当社の届出排出量等におけるトルエンとキシレンの推移. 
する環境事業本部では環境計量証明事業も行っており, 特に ダイオキシン類分析業務において多くのトルエンを抽出溶郕 として使用していることが理由である. なお, 塗装用途の卜 ルエンは大気への排出量として届け出ており, 抽出溶剤とし てのトルエンのほとんどは廃棄物への移動量として届け出て いる．当部署では，日頃から分析作業手順の見直しや改善に 取り組み，省溶媒を目的とした自動分析装置を開発して活用 するなど，トルエン使用量の削減活動に継続的に取り組むこ とで, 排出量の低減に成功している.

キシレンの排出は機械製品の塗装によるものである. 当社 の工場移転等の理由により平成 19 年度からの報告となるが, 粉体塗装設備を導入してスプレ一塗装から粉体塗装に切り替 える活動を行った結果，平成 20,21年度にはキシレン排出量 の低減に成功している。なお，工場の移転や増築，事業内容 や経営状況の変化に伴い, 届出排出量等には変動があること をご承知頂きたい。

\section{6. より詳しく知るために}

本稿で紹介した経済産業省と環境省のHPには, PRTR 制度に関する詳しい解説が掲載されており，また，詳細な PRTRデータも公表されているので，ご参照頂けたら幸いで ある。

\section{引用文 献}

1) http://www.meti.go.jp/policy/chemical_management/law/(2015 年10月27日閲覧).

2) http://www.meti.go.jp/policy/chemical_management/law/prtr/ index.html（2015年10月27日閲覧）.

3） PRTR排出量等算出マニュアル 第 4.1 版 : 経済産業省・環境省 (平成 23 年 3 月).

4) 平成 25 年度PRTRデータの概要 http://www.meti.go.jp/policy/ chemical_management/law/prtr/h25kohyo/gaiyou.html（2015年 10月27日閲覧)

5) 斎藤幸保：やさしいPRTR法届出の仕方, 日刊工業新聞社, 2002.

\section{略 歴}

高橋知史（たかはし ともふみ）

生年月日：1974年生まれ

最終学歴：1999年3月広島大学大学院工学研究科移動現象工 学専攻修士課程修了

研究テーマ：多孔性シリカ薄膜による有機ガス分離, 高活性 酸化カルシウムによる有機塩素化合物の分解, 絶縁油中の PCB簡易測定法の開発

主な職歴：1999年 4 月三浦工業株式会社入社, 水処理事業 部を経て, 現職の環境事業本部。現在は, PCB・ DXN類に代表される環境ホルモン物質等の分析業 務及び分析技術開発に携わっている.

趣味：サンデーメカニック 